\title{
Indomethacin Use for Mild \& Moderate hospitalised Covid-19 patients: An open label randomized clinical trial
}

\author{
Rajan Ravichandran ${ }^{1}$, Surapaneni Krishna Mohan ${ }^{2}$, Suresh Kumar Sukumaran ${ }^{3}$, Devakumar \\ Kamaraj $^{4}$, Sumetha Suga Daivasuga ${ }^{5}$, Samson Oliver Abraham Samuel Ravi ${ }^{6}$, Sivakumar \\ Vijayaraghavalu ${ }^{7}$, Ramarathnam Krishna Kumar $^{8^{*}}$ \\ ${ }^{1}$ Department of Nephrology, MIOT International, Chennai 600089, India and Adjunct Faculty, Indian Institute of \\ Technology Madras (IITM), Chennai 600036, Tamil Nadu (TN), India. \\ ${ }^{2}$ Departments of Biochemistry, Molecular Virology \& Research, Panimalar Medical College Hospital \& Research \\ Institute, Chennai 600123, TN, India. \\ ${ }^{3}$ Department of General Medicine, Panimalar Medical College Hospital \& Research Institute, Chennai 600123, \\ TN, India.
}

${ }^{4}$ Departments of Pharmacology \& Research, Panimalar Medical College Hospital \& Research Institute, Chennai 600123, TN, India.

${ }^{5}$ Departments of Microbiology \& Molecular Virology, Panimalar Medical College Hospital \& Research Institute, Chennai 600123, TN, India.

${ }^{6}$ Molbio Diagnostics Private Limited, Verna Industrial Estate, Verna, Goa - 403 722, India

${ }^{7}$ Narayana Translational Research and Incubation Center, Narayana Medical College, Nellore 524003, Andhra Pradesh, India and Adjunct Faculty, IITM, Chennai 600036, TN, India.

${ }^{8}$ Department of Engineering Design, IITM, Chennai 600036, TN, India.

*Corresponding Author

Professor R. Krishna Kumar, Department of Engineering Design, Indian Institute of Technology Madras, Chennai 600036, Tamil Nadu, India

E-mail: rkkumar@iitm.ac.in

KEY WORDS: Covid-19, Indomethacin, clinical recovery, Inflammation.

\section{Conflict of Interest}

We have read and understood the policy on declaration of interests and declare that we have no competing interests. 
medRxiv preprint doi: https://doi.org/10.1101/2021.07.24.21261007; this version posted October 3, 2021. The copyright holder for this preprint (which was not certified by peer review) is the author/funder, who has granted medRxiv a license to display the preprint in perpetuity.

It is made available under a CC-BY-ND 4.0 International license .

\begin{abstract}
Introduction

Indomethacin, a non-steroidal anti-inflammatory drug (NSAID), has been presented as a broad-spectrum antiviral agent. This randomised clinical trial in a hospital setting evaluated the efficacy and safety of this drug in RT-PCR-positive coronavirus disease 2019 (COVID-19) patients.
\end{abstract}

\title{
Materials \& Methods
}

A total of 210 RT-PCR-positive COVID-19 patients, who provided consent were allotted, to control or case arm, based on block randomisation. The control arm received standard of care comprising paracetamol, ivermectin, and other adjuvant therapies. The patients in the case arm received indomethacin instead of paracetamol, with other medications retained. The primary endpoint was the development of hypoxia/desaturation with $\mathrm{SpO}_{2} \leq 93$, while time to become afebrile and time for cough and myalgia resolution were the secondary endpoints.

\section{Results}

The results of 210 patients were available, with 103 and 107 patients in the indomethacin and paracetamol arms, respectively. We monitored patient profiles along with everyday clinical parameters. Blood chemistry at the time of admission and discharge was assessed.

As no one in either of the arms required high-flow oxygen, desaturation with $\mathrm{SpO}_{2}$ level of 93 and below was an important goal. In the indomethacin group, none of the 103 patients developed desaturation. On the other hand, 20 of the 107 patients in the paracetamol arm developed desaturation. Patients who received indomethacin also experienced more rapid symptomatic relief than those in the paracetamol arm, with most symptoms disappearing in half the time. 56 patients out of 107 in the paracetamol arm had fever on the seventh day, while no patient in the indomethacin group had fever. Neither arm reported any adverse event. The fourteenth-day follow-up revealed that the paracetamol 
medRxiv preprint doi: https://doi.org/10.1101/2021.07.24.21261007; this version posted October 3, 2021. The copyright holder for this preprint (which was not certified by peer review) is the author/funder, who has granted medRxiv a license to display the preprint in perpetuity. It is made available under a CC-BY-ND 4.0 International license .

arm patients had faced several discomforts, including myalgia, joint pain, and tiredness; indomethacin arm patients mostly complained only of tiredness.

\section{Conclusion}

Indomethacin is a safe and effective drug for treating patients with mild and moderate covid-19. 
medRxiv preprint doi: https://doi.org/10.1101/2021.07.24.21261007; this version posted October 3, 2021. The copyright holder for this preprint (which was not certified by peer review) is the author/funder, who has granted medRxiv a license to display the preprint in perpetuity.

It is made available under a CC-BY-ND 4.0 International license .

\section{Introduction}

SARS-Cov-2, a member of the coronavirus family, has been ravaging the world for the past 18 months. Although an effective treatment has eluded the medical community, there have been several registered trials on finding new or repurposed drugs. Several studies have discussed the mechanism of the virus-host interaction and possible treatments [1] but a safe and effective treatment for the disease is yet to emerge. Drug repurposing seems to be an immediate solution and various drugs have been suggested for COVID-19 treatment [2, 3].

The drugs required to combat the pathogen may fall into one or more of the following categories: antivirals, anti-inflammatory agents, and supporting therapies [4, 5]. According to V'Kovski, [1] the antiviral action can be based on the stages of viral-host interactions. These include attachment and virus neutralisation, host protease inhibitors that stop the entry of the virus, viral protease inhibitors, viral RdRp inhibitors, and viral maturation inhibitors. Frediansyah et al. [6] enumerated the possible antiviral solutions at various stages of interactions. The role of cathepsin $L$ in cleavage of the $S$ protein complex and subsequent release of virus genome is well documented. Inhibiting cathepsin L inhibits the entry of SARS-Cov-2 by $76 \%$ [7].

Pro-inflammatory cytokine production is natural during immune response. The elimination of virus-infected cells is an important step in disease control. If this step, which naturally follows virus entry and replication, is defective or prolonged, it can result in a cytokine storm,[8] an uncontrolled release of pro-inflammatory cytokines. Several interleukins are involved in a cytokine storm, the foremost being interleukin 6 (IL-6), IL-1,[8] and IL -17 [9]. IL-17 also seems to have a role as the interaction partner of SARS-Cov-2. Anti-inflammatory drugs targeting the production of these interleukins are important for COVID-19 treatment.

\section{Indomethacin as a Drug for SARS-Cov-2}

Amici et al. [10] were the first to identify the antiviral activity of indomethacin. They recorded the antiviral activities of indomethacin against SARS-Cov-1 in vitro. Xu et al. [11] presented evidence of its antiviral activity against SARS-Cov-2. Their investigations covered 
medRxiv preprint doi: https://doi.org/10.1101/2021.07.24.21261007; this version posted October 3, 2021. The copyright holder for this preprint

the antiviral effect of indomethacin in vitro, cellulo, corona-infected canine models. They also stated that indomethacin does not reduce infectivity, binding, or entry into target cells. This conclusion is based on the results of Amici et al. [10] for SARS-Cov-1, although computer models have indicated otherwise [12]. Downregulation of ACE2 and TMPRSS2 is important to reduce infectivity. Using an open-source code, Gene2Drug, Napolitano et al.,[12] showed in a computer model that indomethacin downregulates ACE2 by suppressing the genes in the ACE2 pathway. Raghav et al. [13] depicted the role of indomethacin in inhibiting cathepsin L activity required for fusion. Interestingly, no other non-steroidal antiinflammatory drugs [13] projected this quality.

Non-Structural Protein7 (Nsp7), along with Nsp12, is important for RNA synthesis, as highlighted by Frediansyah et al. [6], Gordan et al. [9] recognised that prostaglandin E synthase 2 (PGES-2) is an "interactor" with Nsp7, and indomethacin inhibits PGES-2 . Hence, indomethacin is an important candidate for blocking RNA synthesis. Amici et al. [10] reported of this block of RNA synthesis. Amici et.al [14] also demonstrated that protein kinase $R$ (PKR) activation by indomethacin results in inhibition of virus protein translation. This follows the work of Brunelli et al. [15] , where the role of indomethacin in activating PKR directly has been demonstrated.

Several publications $[16,17]$ have highlighted the importance of preventing inflammation in Covid-19 patients. Indomethacin downregulates IL- 6 by inhibiting the synthesis of PGES-2 [18]. Indomethacin has been successful in preventing cytokine reactions in kidney transplant patients receiving OKT3 therapy $[19,20]$.

Rajan et al. [21] conducted one of the first indomethacin trials. Using the data from an open-label single-arm data for indomethacin, they showed the effect of indomethacin as a treatment option by matching propensity score with retrospectively collected data on paracetamol. Gordon et al. [9] showed by retrospective data analysis that indomethacin markedly reduces the need for hospitalisation. Two studies [22, 23] have shown the effectiveness of indomethacin in treating a small number of SARS-Cov-2 patients with severe comorbidities. However, these were small case series, and a larger controlled trial is required to validate these findings.

The primary objective in this study is to determine the percentage of desaturating patients. As a quantitative criteria $\mathrm{SpO}_{2} \leq 93$ has been used as a measure. The secondary outcome was symptomatic relief. Time to become afebrile, relief from cough and myalgia are the 
medRxiv preprint doi: https://doi.org/10.1101/2021.07.24.21261007; this version posted October 3, 2021. The copyright holder for this preprint (which was not certified by peer review) is the author/funder, who has granted medRxiv a license to display the preprint in perpetuity. It is made available under a CC-BY-ND 4.0 International license.

major symptoms for the secondary outcome. The safety profile of indomethacin was also monitored as a secondary outcome.

\section{Methods}

\section{Study Design}

This open label randomized clinical trial consisted of two parallel groups; the control group with paracetamol and standard of care $(\mathrm{SOC})$ and the indomethacin group with SOC. We recruited RT-PCR positive covid-19 patients using four and six block randomisation parallel group protocol [24]. The protocol was computer generated and all care were taken to conceal the allocation of patients from the treating physicians. They were not involved either in the randomisation or the allocation. The randomization was handled by a third person, not involved either in the treatment or in data collection. To understand the impact of the sample size, we assumed the response rate for paracetamol and indomethacin to be 0.82 and 0.95 , respectively. The sample size was calculated using $R$ with an alpha value of 0.05. The marginal power was of 0.8 [25]. The sample size worked out to be 95 in each group. The study was conducted at Panimalar Medical College, Chennai, India, in a designated Covid ward. Fig. 1 describes the study design.

\section{Study Cohort}

The patients recruited were RT-PCR positive. The clearly defined inclusion and exclusion criteria are given below.

Inclusion

- Age between 20 and 90 years

- $\quad$ RT-PCR positive

- Hospitalised patients

- The case criteria for the study:

- Oxygen saturation - 94 or more

Exclusion

- Hypersensitivity/Allergy to drugs

- Gastritis 
- Recent heart attack

- Severe asthma

- Acute kidney injury

- Patients on immunosuppressants

- Pregnant \& lactating mothers

- Indomethacin allergy

The trial was approved by the Panimalar Medical College Hospital \& Research Institute Institutional Human Ethics Committee with a CDSCO Registration Number: ECR/1399/INST/2020. The approval Number for the trial is PMCH\&RI/IHEC/2021/051. The trial was also registered with Clinical Trial Registry of India (CTRI/2021/05/033544) of the ICMR. . The patients were apprised of the trial and the background before obtaining their informed consent which were made available in English and the vernacular language.

\section{Treatment}

Indomethacin replaced paracetamol and was given along with the hospital standard care, which included doxycycline and ivermectin. The standard of care was decided by the government regulated protocol, followed in many hospitals throughout India. However, studies have shown that ivermectin may not be effective in treating covid-19 patients [26]. We also added a proton pump inhibitor along with indomethacin. The drugs and their dosage are listed in Table 1.

The treatment regimen was for five days.

\begin{tabular}{|l|l|l|l|}
\hline S.No & Drug & Dose \& Duration & $\begin{array}{l}\text { Timing Before/After Food } \\
(\mathbf{B F} / \mathrm{AF})\end{array}$ \\
\hline 1 & C. Doxycycline & $100 \mathrm{mg}$ BD & AF \\
\hline 2 & T. Ivermectin & $12 \mathrm{mg}$ OD & AF \\
\hline 3 & T. Vitamin C & $500 \mathrm{mg}$ BD & AF \\
\hline 4 & T. Zinc & $50 \mathrm{mg}$ OD & AF \\
\hline $5 a$ & T. Indomethacin & $75 \mathrm{mg}$ & $\begin{array}{l}0-0-1 \text { for BMI }<30 \\
1-0-1 \text { for BMI }>30\end{array}$ \\
\hline
\end{tabular}




\begin{tabular}{|l|l|l|l|}
\hline $5 \mathrm{~b}$ & $\begin{array}{l}\text { In the paracetamol arm } \\
\text { (Dolo 650) instead of } \\
\text { indomethacin }\end{array}$ & $650 \mathrm{mg}$ & $1-1-1-1$ \\
\hline 6 & Cough syrup - (Lupituss) & $5 \mathrm{ml}$ TDS & $1-1-1$ \\
\hline 7 & T. Pantoprazole & $40 \mathrm{mg}$ BD & $1-0-1$ \\
\hline
\end{tabular}

Table 1 Drug chart

\section{Measurements}

The following investigations were conducted on admission: CT scan of the lungs, liver function test (LFT), kidney function test (KFT), C-reactive protein (CRP), and D-dimer as well regular blood tests such as complete blood count. We repeated blood chemistry on discharge and monitored the well-being of the patients after discharge for 14 days through telephonic communication. We also monitored the patients for clinical symptoms such as oxygen saturation, fever, cough, and myalgia for seven days at the hospital. Patients were deemed symptomatically recovered if the temperature dropped below $99^{\circ} \mathrm{F}$ for two days and cough reduced to a score 1 on a one-to-ten scale (1: no cough; 2-3: cough sometimes; 4-6: coughing with the ability to do things; 7-8 persistent cough; 9-10: great deal of discomfort). RT-PCR was mandatory on admission and for 122 patients, RT-PCR was repeated on the seventh day, before discharge.

\section{Statistical Analysis}

We used standard statistical parameters to analyze the recruited patients. The patients in the two arms were also compared based on mean/median, interquartile range (IQR) and the Wilcoxon test to estimate the p-values. Wherever appropriate $95 \%$ confidence interval $(\mathrm{Cl})$ was calculated. The test of significance for $p$-value was based on a p-value of 0.01 . We followed the dictum "once randomized always analyzed". The primary end point was examined using chi-squared test and the secondary end points were also studied based on mean, IQR and p-values calculated using Wilcoxon test.

We used linear regression and non-linear regression to analyze the reduction in C-Reactive protein. To comprehend the time for symptomatic relief clearly, we also carried out KaplanMeir survival analysis and used Cox regression to understand the effect of covariates. These two results are presented in Supplementary Section. 


\section{Results}

Our goal in this study was to recruit 300 patients. The results presented here are for the first 210 patients and is an interim report. As Randomization resulted in 107 patients in the paracetamol group and 103 patients in the indomethacin group.

\section{Patient Characteristics and Disposition}

Patient profiles are shown in Fig. 2 and Table 2. The age profile and gender-wise enumeration match closely in both groups. The temperature on admission had a marginal bias, being higher for patients in the indomethacin group. In addition, more patients in the indomethacin group had severe cough (above Scale 7). The co-morbidity distribution was similar. No patient was lost in the follow up.

\begin{tabular}{|c|c|c|c|}
\hline Characteristics & $\begin{array}{l}\text { All } \\
(\mathrm{N}=\mathbf{2 1 0})\end{array}$ & $\begin{array}{l}\text { Paracetamol } \\
(\mathrm{N}=107)\end{array}$ & $\begin{array}{l}\text { Indomethacin } \\
(\mathrm{N}=103)\end{array}$ \\
\hline Gender (Female/Male) & $(86 / 124)$ & $(44 / 63)$ & $(42 / 61)$ \\
\hline Age (mean \pm sd) & $47.04 \pm 16.0$ & $47.0 \pm 15.21$ & $47.07 \pm 16.86$ \\
\hline $\begin{array}{l}\text { Age (Male) } \\
(\text { mean } \underline{t} \text { sd) }\end{array}$ & $48.21 \pm 15.47$ & $48.04 \pm 14.75$ & $48.4 \pm 16.36$ \\
\hline $\begin{array}{l}\text { Age (Female) } \\
(\text { mean } \pm \text { sd })\end{array}$ & $45.33 \pm 16.66$ & $45.41 \pm 15.93$ & $45.25 \pm 17.55$ \\
\hline $\begin{array}{l}\text { Temperature on } \\
\text { admission }\end{array}$ & $100.1 \pm 1.5$ & $99.8 \pm 1.5$ & $100.5 \pm 1.4$ \\
\hline $\begin{array}{l}\text { Cough on admission } \\
\text { a) Scale - } 7 \text { to } 10 \\
\text { b) Scale - } 2 \text { to } 6\end{array}$ & $\begin{array}{l}57 \\
88\end{array}$ & $\begin{array}{l}21 \\
54\end{array}$ & $\begin{array}{l}36 \\
34\end{array}$ \\
\hline $\begin{array}{l}\text { orbidities } \\
\text { pertension }\end{array}$ & $\begin{array}{l}61 \\
40\end{array}$ & $\begin{array}{l}28 \\
25\end{array}$ & $\begin{array}{l}33 \\
15\end{array}$ \\
\hline
\end{tabular}

Table 2 The profile of the recruited patients 
medRxiv preprint doi: https://doi.org/10.1101/2021.07.24.21261007; this version posted October 3, 2021. The copyright holder for this preprint (which was not certified by peer review) is the author/funder, who has granted medRxiv a license to display the preprint in perpetuity.

It is made available under a CC-BY-ND 4.0 International license .

\section{Efficacy Analysis}

Symptomatic relief is very important for the psychological and physiological well-being of patients. We monitored the number of days to become afebrile, days for reduction of cough, and relief from myalgia. The results are presented in Fig. 3a for afebrile, Fig. 3b for number of days for cough reduction, Fig. $3 \mathrm{c}$ for cough reduction with a higher score on admission, Fig. 3d with lower cough score on admission and Fig. 3e for myalgia reduction.

Median (dark line) and interquartile ranges are shown as boxes. The symptomatic recovery from fever and cough in terms of median values are given in Table 3 . Two points are significant from the table and figure. Symptomatic relief with indomethacin takes only half the time compared to paracetamol. Additionally, the IQR, a measure of statistical dispersion, is very small with indomethacin compared to that of paracetamol. This is significant because the action of indomethacin is almost independent of the condition of patient on admission. The $p$-value in the figure indicates statistical significance.

\begin{tabular}{|c|c|c|c|c|c|c|c|c|c|}
\hline \multirow{2}{*}{ Treatment } & \multicolumn{3}{|c|}{ Days to become Afebrile } & \multicolumn{3}{|c|}{$\begin{array}{l}\text { Days for } \\
\text { Reduction }\end{array}$} & \multicolumn{3}{|c|}{$\begin{array}{l}\text { Days for } \\
\text { Reduction }\end{array}$} \\
\hline & Median & $\begin{array}{l}95 \% \\
\text { CI }\end{array}$ & IQR & Median & $\begin{array}{l}95 \% \\
\text { CI }\end{array}$ & IQR & Median & $95 \%$ CI & IQR \\
\hline Indomethacin & 3 & $3.0,3.0$ & 1 & 4 & $\begin{array}{l}4.0 \\
5.0\end{array}$ & 1 & 4 & $3.0,4.0$ & 2 \\
\hline Paracetamol & 7 & $6.0,7.0$ & 2.75 & 7 & $\begin{array}{l}7.0 \\
8.0\end{array}$ & 3 & 7 & $5.0,7.0$ & 2 \\
\hline
\end{tabular}

Table 3 Symptomatic relief due to various treatments

Further results are provided in the supplementary appendix. They provide the Kaplan-Meir estimator for the time for relief of three symptoms, namely fever, cough and myalgia in Fig. S1 to S3. Also given in the supplementary appendix are the Cox regression analysis (Tables S1 to S3).

The key question is the number of patients desaturating $\left(\mathrm{SpO}_{2} \leq 93\right)$ in both arms. The patients were admitted with a median $\mathrm{SpO}_{2}$ of $95(\mathrm{IQR}=1)$ and $\mathrm{SpO}_{2}$ of $96(\mathrm{IQR}=1)$ in the indomethacin arm and paracetamol arm, respectively, with a minimum $\mathrm{SpO}_{2}$ of 94 . Out of 
medRxiv preprint doi: https://doi.org/10.1101/2021.07.24.21261007; this version posted October 3, 2021. The copyright holder for this preprint (which was not certified by peer review) is the author/funder, who has granted medRxiv a license to display the preprint in perpetuity.

It is made available under a CC-BY-ND 4.0 International license .

107 patients, 20 desaturated in the paracetamol arm, while none desaturated in the indomethacin arm. No patient required high-flow oxygen; prone position and occasional low-flow oxygen was sufficient. In the indomethacin arm, saturation improved in one or two doses. The results are presented in Fig. 4.

CRP is a well-known inflammatory marker, implicating covid-19 as a severe disease. According to Liu et al.,[16] a CRP score greater than 41.8 may lead to a severe disease. Fig. 5 shows the relationship between the CRP level on admission and the decrease in the CRP level on the seventh day. Fig. 6 shows the relationship between CRP on admission with a value greater than 41 and a reduction in CRP. Although the information in Fig. 6 is available in Fig.5, the separation provides clarity of data.

The results of the RT-PCR test conducted on the seventh day are presented in Fig. 7. As can be seen from the figure, more patients became RT-PCR negative on the seventh day in the indomethacin arm although the p-value was 0.42 .

Post-hoc calculations based on actual results yielded a marginal power of 0.99 .

\section{Safety Analysis}

Indomethacin was approved in 1965. However, there have been concerns regarding its safety [27]. The number of prescriptions for indomethacin were 2.16 million [28] in 2018, in the US alone. Patients were tested for serum urea and creatinine, SGOT and SGPT before and after the treatment, and the results are shown in Fig. 8 and Fig. 9.

Fig. 8 and Fig. 9 show statistical similarity between both arms. Neither the liver nor kidney function deteriorated after treatment in either arm. Neither the Patients nor the attending physicians did not report any other side-effects.

\section{Discussion}

The primary aim of the study was to understand the efficacy of indomethacin in preventing desaturation $\left(\mathrm{SpO}_{2} \leq 93\right)$ and deterioration in mild and moderate covid-19 patients and compare this with a paracetamol-based arm. The secondary aim was to evaluate symptomatic relief in indomethacin patients compared to paracetamol patients. The results are striking: Indomethacin arm patients did not develop desaturation, while nearly 20 per cent of the paracetamol arm patients developed desaturation. When the $\mathrm{SpO}_{2}$ level dips below 93, we managed the patient with either low-flow oxygen or by placing them in prone 
medRxiv preprint doi: https://doi.org/10.1101/2021.07.24.21261007; this version posted October 3, 2021. The copyright holder for this preprint

position to enhance breathing. No patient in this study showed further deterioration. Notably, SpO2 improved just after one or two doses in the indomethacin arm. Patients with a marginal SpO2 level of 94 showed an improvement. At the end of the seventh day, 13 patients in the paracetamol arm were at a SpO2 level of 94. In the indomethacin arm, only two patients had SpO2 levels of 94, while 97 of the 103 patients had a higher SpO2 level, higher than 97. In the paracetamol arm only 51 patients (out of 107 patients) had a $\mathrm{SpO}_{2}$ level higher than 97.

Symptomatic relief was even more salient. The median time for becoming afebrile was three and seven days in the indomethacin and paracetamol arm, respectively. The median time for cough reduction was four days and seven days in the indomethacin and paracetamol arm, respectively. 59 out of 107 patients in the paracetamol arm had fever on the seventh day while none of the indomethacin arm patients did. 49 of 75 patients taking paracetamol took seven or more days to recover from cough; only nine out of 70 patients in the indomethacin arm took seven days or more to recover and they were at level 2 in the ordinal scale. No patient in the indomethacin arm required continuation of indomethacin after the five-day regimen. On the other hand, patients who were not afebrile after the treatment regimen of five days in the paracetamol arm were continued with the paracetamol at the discretion of the treating physician. One of the most important conclusions came from analysing the IQR. Fig. $3 a$ and $3 b$ show a very thin IQR band for fever and cough reduction in indomethacin patients, along with a small error bar, compared to paracetamol patients. A marginally broader IQR brand in myalgia may indicate the subjective nature of relief.

Kaplan-Meir estimator reinforces the conclusion of the benefit of indomethacin strikingly. All the figures in the supplementary appendix show a big gap between the two treatments. Cox regression results indicate that, the hazard ratio with the treatment of indomethacin is highly significant compared to other covariates. Indomethacin improves the recovery time by 85 to $90 \%$ for symptomatic relief. The other covariates that have an effect on cough recovery are the $\mathrm{CT}$ Score on admission and cough on admission. Fever reduction and myalgia resolution are not affected by the covariates.

The results are similar to our earlier study which used propensity score matching [21]. In that study, the median time for becoming afebrile, cough reduction, and myalgia relief in 
medRxiv preprint doi: https://doi.org/10.1101/2021.07.24.21261007; this version posted October 3, 2021. The copyright holder for this preprint (which was not certified by peer review) is the author/funder, who has granted medRxiv a license to display the preprint in perpetuity.

It is made available under a CC-BY-ND 4.0 International license .

the indomethacin arm was four, three, and four days, respectively. However, the median in the paracetamol arm was seven and eight and 6.5 days, respectively.

We monitored CRP on admission and discharge. Indomethacin is very effective in reducing CRP in patients with higher CRP levels on admission (> $41 \mathrm{mg} / \mathrm{L}$ ). The $\mathrm{R} 2$ value for indomethacin (0.85) was much higher compared to paracetamol (0.1). Thus, we can conclude that the consistency of indomethacin in reducing inflammation is very high.

A fourteen-day follow-up further revealed the efficacy of the drug. In the indomethacin arm, nearly $50 \%$ patients had fully recovered compared to $28 \%$ in the paracetamol arm. The major complaint of the $50 \%$ of patient who took indomethacin was tiredness. Only $14 \%$ of the patients had myalgia while $10 \%$ complained of joint pain. On the other hand, in the paracetamol arm, the recovery was slower with $47 \%$ complaining of myalgia, $48 \%$ of tiredness, $39 \%$ of joint pain and 33\% complaining of other ailments.

Alkotaji et.al. [29] had hypothesised the importance of indomethacin in reducing cough and myalgia through its inhibitive action on bradykinin and the mechanism and ill-effects of bradykinin are well documented. The theory proposed in this study explains the difference in symptomatic relief between the two groups.

We had hypothesised that early symptomatic relief is important for recovery and prevents desaturation. 17 of the 20 patients who desaturated had fever beyond seven days and eleven had cough beyond seven days. The fourteenth-day state of the patients also reflected this.

The viral load reduction was better for indomethacin. However, the difference was not significant. Seven days may be too early for an RT-PCR test.

\section{Limitation of the Study}

The limitation of the study is that indomethacin was administered with standard care and not as a stand-alone treatment. With this result, indomethacin may be tried as a standalone treatment. This is not a double blinded study. The trial involved only hospitalised patients and not under home isolation. 
medRxiv preprint doi: https://doi.org/10.1101/2021.07.24.21261007; this version posted October 3, 2021. The copyright holder for this preprint (which was not certified by peer review) is the author/funder, who has granted medRxiv a license to display the preprint in perpetuity.

It is made available under a CC-BY-ND 4.0 International license.

\section{Conclusions}

The use of indomethacin alongside standard treatment protocol in hospitalised covid-19 patients was associated with marked symptomatic relief and improved oxygen saturation level. We did not observe any adverse effects.

\section{Supplementary Data}

Anonymised Patient data are given in supplementary data file 1. If further data is required please contact the corresponding author.

\section{Acknowledgement}

The authors acknowledge the generous funding for this study by Mr. Kris Gopalakrishnan, Alumnus, Indian Institute of Technology Madras.

\section{Funding}

Funding for this study was provided by Mr. Kris Gopalakrishnan, Alumnus of the Indian Institute of Technology Madras. He is also the Chairman of Axilor Ventures. He did not participate in the study in anyway.

\section{References}

1. V'kovski P, Kratzel A, Steiner S, Stalder H, Thiel V. Coronavirus biology and replication: implications for SARS-CoV-2. Nature Reviews Microbiology. ,2021;19(3):155-70.

2. Gordon DE, Jang GM, Bouhaddou $\mathrm{M}, \mathrm{Xu}$ J, Obernier $\mathrm{K}$, White $\mathrm{KM}$, et al. A SARS-CoV-2 protein interaction map reveals targets for drug repurposing. Nature. ,2020;583(7816):459-68.

3. Wang X, Guan Y. COVID-19 drug repurposing: A review of computational screening methods, clinical trials, and protein interaction assays. Medicinal Research Reviews. ,2021;41(1):5-28.

4. Zhao M-M, Yang W-L, Yang F-Y, Zhang L, Huang W-J, Hou W, et al. Cathepsin L plays a key role in SARS-COV-2 infection in humans and humanized mice and is a promising target for new drug development. Signal Transduction and Targeted Therapy. 
medRxiv preprint doi: https://doi.org/10.1101/2021.07.24.21261007; this version posted October 3, 2021. The copyright holder for this preprint (which was not certified by peer review) is the author/funder, who has granted medRxiv a license to display the preprint in perpetuity.

It is made available under a CC-BY-ND 4.0 International license .

,2021;6(1):134.

5. Gomes CP, Fernandes DE, Casimiro F, da Mata GF, Passos MT, Varela P, et al. Cathepsin L in COVID-19: From Pharmacological Evidences to Genetics. Frontiers in Cellular and Infection Microbiology. ,2020;10.

6. Frediansyah A, Tiwari R, Sharun K, Dhama K, Harapan H. Antivirals for COVID-19: A critical review. Clinical Epidemiology and Global Health. ,2021;9:90-8.

7. Gil C, Ginex T, Maestro I, Nozal V, Barrado-Gil L, Cuesta-Geijo MÁ, et al. COVID-19: Drug Targets and Potential Treatments. Journal of Medicinal Chemistry. ,2020;63(21):12359-86.

8. Soy $\mathrm{M}$, Keser $\mathrm{G}$, Atagündüz $\mathrm{P}$, Tabak F, Atagündüz I, Kayhan S. Cytokine storm in COVID-19: pathogenesis and overview of anti-inflammatory agents used in treatment. Clinical Rheumatology. ,2020;39(7):2085-94.

9. Gordon DE, Gordon DE, Hiatt J, Bouhaddou M, Rezelj V V, Ulferts S. Comparative host-coronavirus protein interaction networks reveal pan-viral disease mechanisms. Science. ,2020;9403(October):1-38.

10. Amici C, Di Caro A, Ciucci A, Chiappa L, Castilletti C, Martella V, et al. Indomethacin has a potent antiviral activity against SARS coronavirus. Antiviral Therapy. ,2006;11(8):1021-30.

11. Xu T, Gao X, Wu Z, Selinger DW, Zhou Z. Indomethacin has a potent antiviral activity against SARS CoV-2 in vitro and canine coronavirus in vivo. bioRxiv. ,2020;

12. Napolitano F, Gambardella G, Carrella D, Gao X, di Bernardo D. Computational Drug Repositioning and Elucidation of Mechanism of Action of Compounds against SARSCoV-2. arXiv preprint arXiv:200407697. ,2020;

13. Raghav N, Kamboj RC, Singh $\mathrm{H}$. Effect of some steroidal and non-steroidal antiinflammatory drugs on purified goat brain cathepsin L. Indian Journal of Medical Research - Section B Biomedical Research Other Than Infectious Diseases. ,1993;98(AUG.):188-92.

14. Amici C, La Frazia S, Brunelli C, Balsamo M, Angelini M, Santoro MG. Inhibition of viral protein translation by indomethacin in vesicular stomatitis virus infection: role of 
medRxiv preprint doi: https://doi.org/10.1101/2021.07.24.21261007; this version posted October 3, 2021. The copyright holder for this preprint (which was not certified by peer review) is the author/funder, who has granted medRxiv a license to display the preprint in perpetuity.

It is made available under a CC-BY-ND 4.0 International license .

eIF2 $\alpha$ kinase PKR. Cellular Microbiology. ,2015;17(9):1391-404.

15. Brunelli C, Amici C, Angelini M, Fracassi C, Belardo G, Santoro MG. The non-steroidal anti-inflammatory drug indomethacin activates the elF2akinase PKR, causing a translational block in human colorectal cancer cells. Biochemical Journal. ,2012;443(2):379-86.

16. Liu F, Li L, Xu M, Wu J, Luo D, Zhu Y, et al. Prognostic value of interleukin-6, C-reactive protein, and procalcitonin in patients with COVID-19. Journal of Clinical Virology. ,2020;127:104370.

17. Mahmudpour M, Roozbeh J, Keshavarz M, Farrokhi S, Nabipour I. COVID-19 cytokine storm: The anger of inflammation. Cytokine. ,2020;133:155151.

18. Bour AMJ., Westendorp RG., Laterveer J., Bollen ELE., Remarque E. Interaction of indomethacin with cytokine production in whole blood. Potential mechanism for a brain-protective effect. Experimental Gerontology. ,2000;35(8):1017-24.

19. First MR, Schroeder TJ, Hariharan S, Alexander JW, Weiskittel P. The effect of indomethacin on the febrile response following OKT3 therapy1. Transplantation. ,1992;53(1):91-3.

20. Gaughan WJ, Francos BB, Dunn SR, Francos GC, Burke JF. A Retrospective Analysis of the Effect of Indomethacin on Adverse Reactions to Orthoclone OKT3 in the Therapy of Acute Renal Allograft Rejection. American Journal of Kidney Diseases. ,1994;24(3):486-90.

21. Ravichandran R, Purna P, Vijayaragavan S, Kalavakollu RT, Gaidhane S, Kumar RK. Efficacy and Safety of Indomethacin in Covid-19 patients. medRxiv. ,2020;2020.12.14.20245266.

22. Rajan R, Subramanian S, Clark C. Low dose indomethacin for symptomatic treatment of COVID-19. International Journal of Medical Reviews and Case Reports. ,2020;(0):1.

23. Kanakaraj A, Ravichandran R. Low Dose Indomethacin in the Outpatient Treatment of COVID-19 in Kidney Transplant Recipients - A Case Series. OALib. ,2020;07(10):1-8.

24 Saghaei M. Random allocation software for parallel group randomized trials. $\underline{\mathrm{BMC}}$ Medical Research Methodology. ,2004;4(1):26. 
medRxiv preprint doi: https://doi.org/10.1101/2021.07.24.21261007; this version posted October 3, 2021. The copyright holder for this preprint (which was not certified by peer review) is the author/funder, who has granted medRxiv a license to display the preprint in perpetuity. It is made available under a CC-BY-ND 4.0 International license.

25. Sakpal T. Sample size estimation in clinical trial. Perspectives in clinical research. ,2010;1(2):67.

26. Momekov G, Momekova D. Ivermectin as a potential COVID-19 treatment from the pharmacokinetic point of view: antiviral levels are not likely attainable with known dosing regimens. Biotechnology \& Biotechnological Equipment. ,2020;34(1):469-74

27. Donnelly P, Lloyd K, Campbell H. Indomethacin in rheumatoid arthritis: an evaluation of its anti-inflammatory and side effects. BMJ. ,1967;1(5532):69-75.

28. Indomethacin drug usage statistics, United States, 2018 [Internet]. 2018. [Available from: https://clincalc.com/DrugStats/Drugs/Indomethacin]

29. Alkotaji M, Al-Zidan RN. Indomethacin: Can It Counteract Bradykinin Effects in COVID19 Patients? Current Pharmacology Reports. ,2021;7(3):102-6.

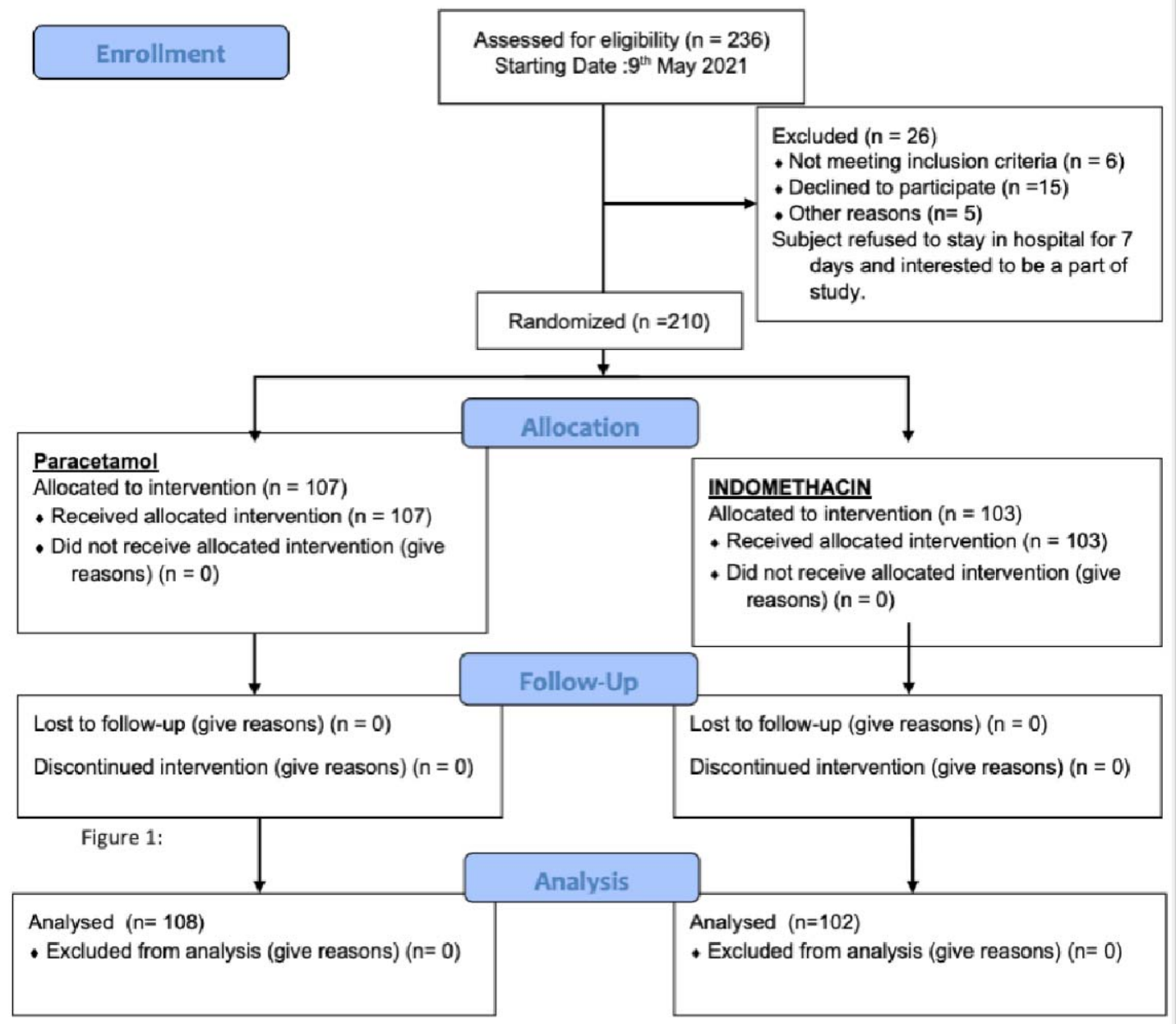


medRxiv preprint doi: https://doi.org/10.1101/2021.07.24.21261007; this version posted October 3, 2021. The copyright holder for this preprint (which was not certified by peer review) is the author/funder, who has granted medRxiv a license to display the preprint in perpetuity.

It is made available under a CC-BY-ND 4.0 International license .

Fig. 1 Flow Diagram

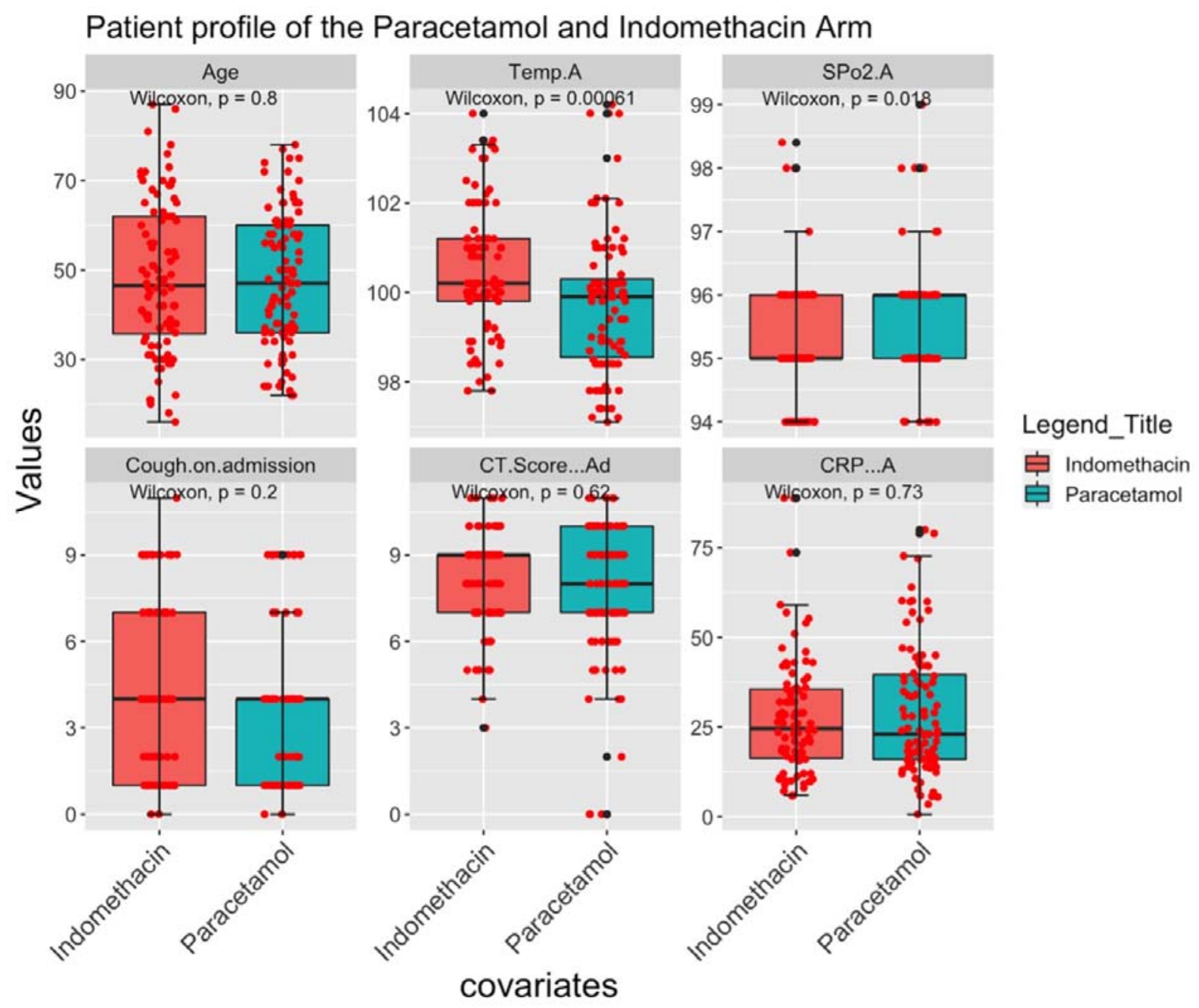

Fig. 2 Patient Profile on admission 
medRxiv preprint doi: https://doi.org/10.1101/2021.07.24.21261007; this version posted October 3, 2021. The copyright holder for this preprint (which was not certified by peer review) is the author/funder, who has granted medRxiv a license to display the preprint in perpetuity.

\section{It is made available under a CC-BY-ND 4.0 International license .}

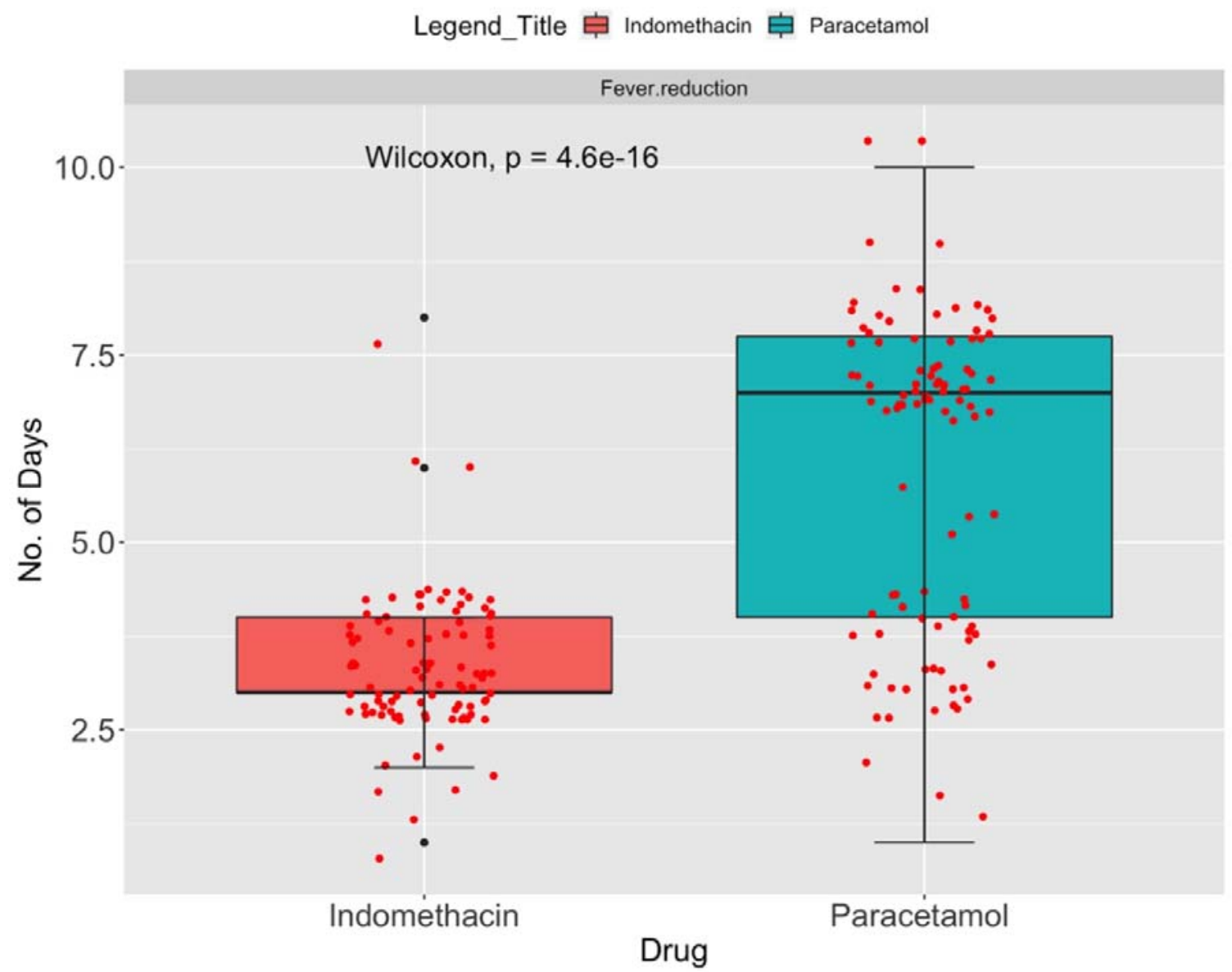

Fig. 3a Number of days for Afebrile. $\mathrm{N}_{\text {indomethacin }}=95 ; \mathrm{N}_{\text {Paracetamol }}=98$ 
medRxiv preprint doi: https://doi.org/10.1101/2021.07.24.21261007; this version posted October 3, 2021. The copyright holder for this preprint (which was not certified by peer review) is the author/funder, who has granted medRxiv a license to display the preprint in perpetuity.

\section{It is made available under a CC-BY-ND 4.0 International license .}

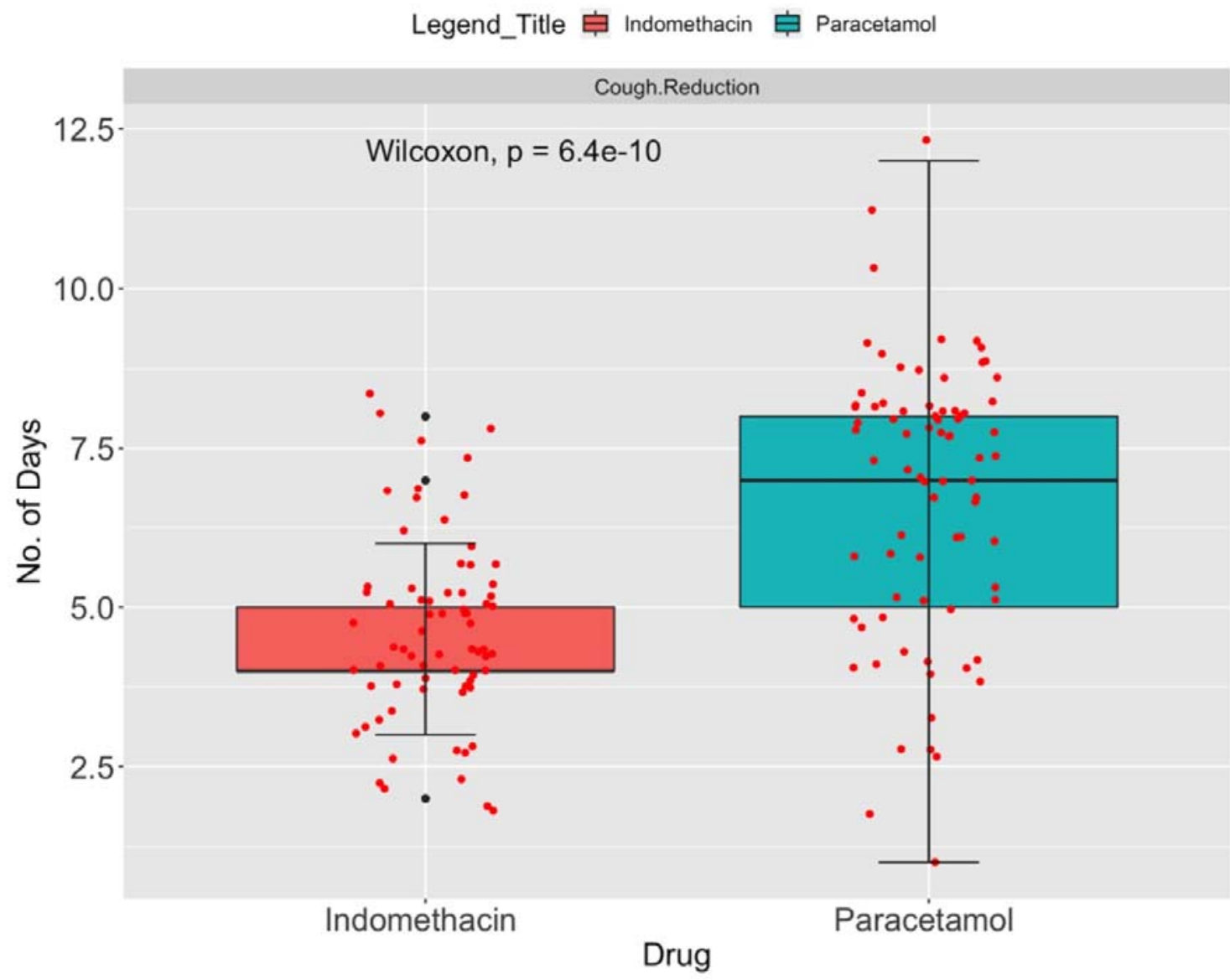

Fig. $3 b$ Number of days of days for cough reduction. $N_{\text {indomethacin }}=70 ; N_{\text {Paracetamol }}=75$ 
medRxiv preprint doi: https://doi.org/10.1101/2021.07.24.21261007; this version posted October 3, 2021. The copyright holder for this preprint (which was not certified by peer review) is the author/funder, who has granted medRxiv a license to display the preprint in perpetuity.

$$
\text { It is made available under a CC-BY-ND } 4.0 \text { International license. }
$$

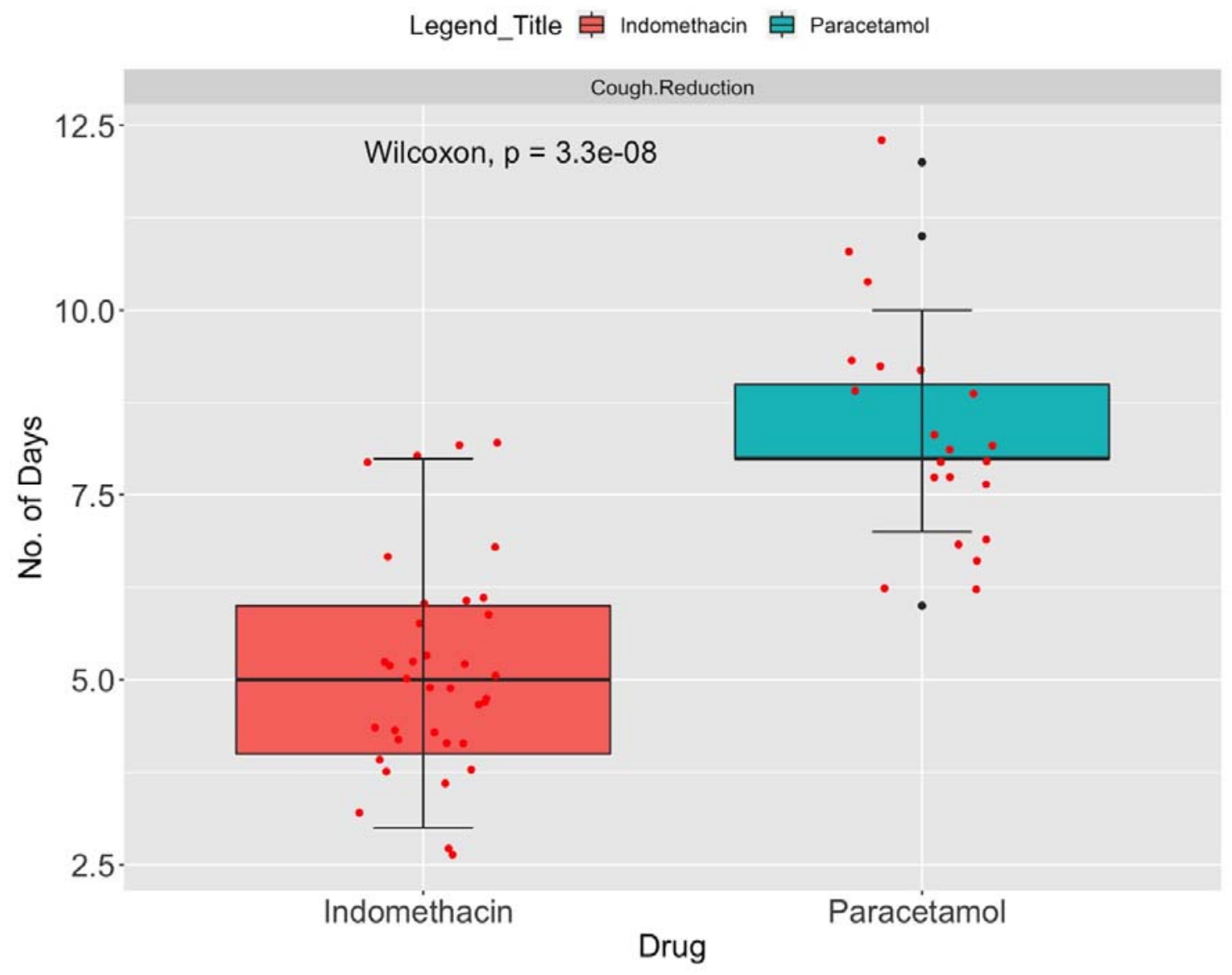

Fig. 3c Number of days of days for cough reduction - Cough on admission 7 to 10 
medRxiv preprint doi: https://doi.org/10.1101/2021.07.24.21261007; this version posted October 3, 2021. The copyright holder for this preprint (which was not certified by peer review) is the author/funder, who has granted medRxiv a license to display the preprint in perpetuity. It is made available under a CC-BY-ND 4.0 International license .

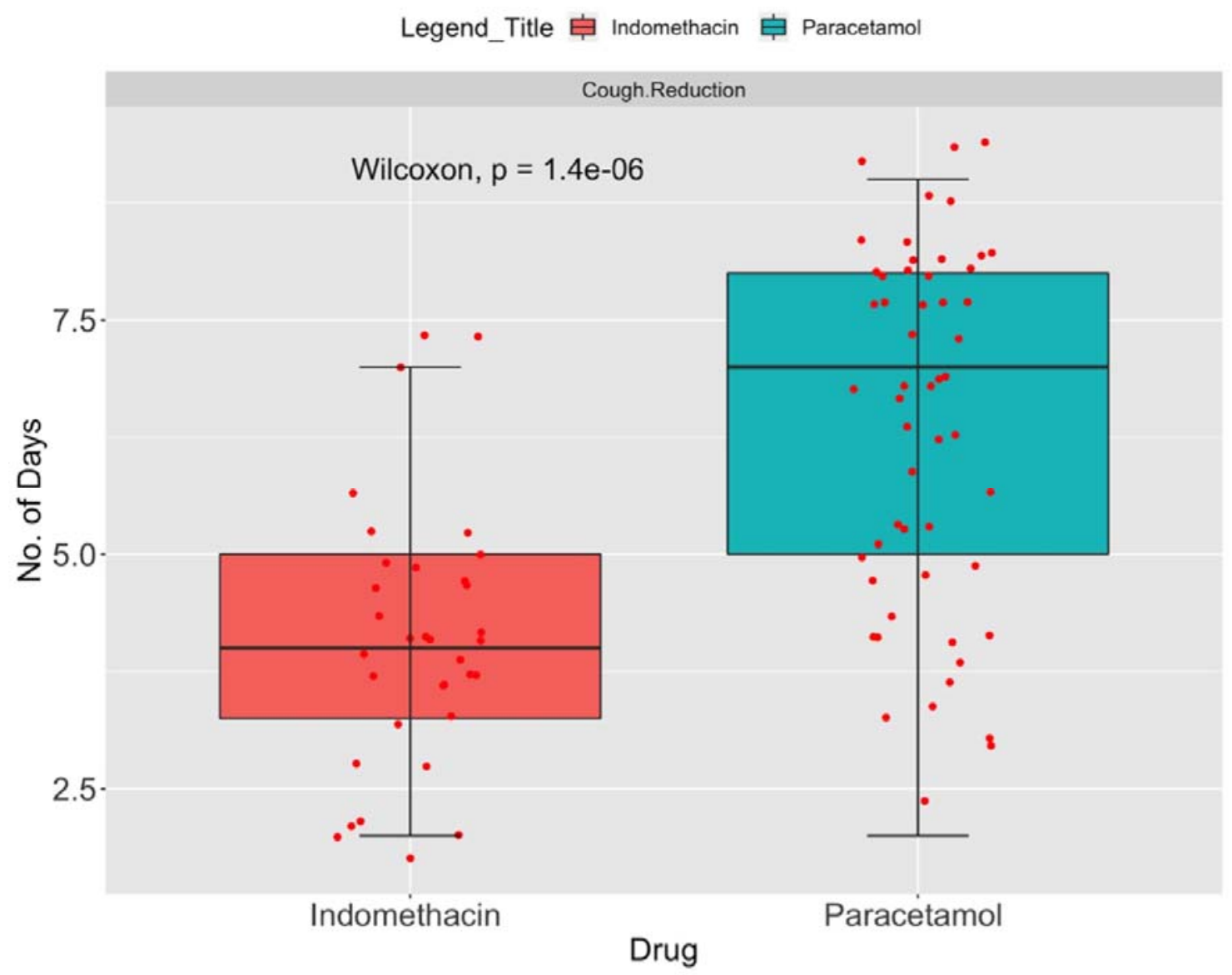

Fig. 3d Number of days of days for cough reduction - Cough on admission 2 to 6 
medRxiv preprint doi: https://doi.org/10.1101/2021.07.24.21261007; this version posted October 3, 2021. The copyright holder for this preprint (which was not certified by peer review) is the author/funder, who has granted medRxiv a license to display the preprint in perpetuity.

\section{It is made available under a CC-BY-ND 4.0 International license .}

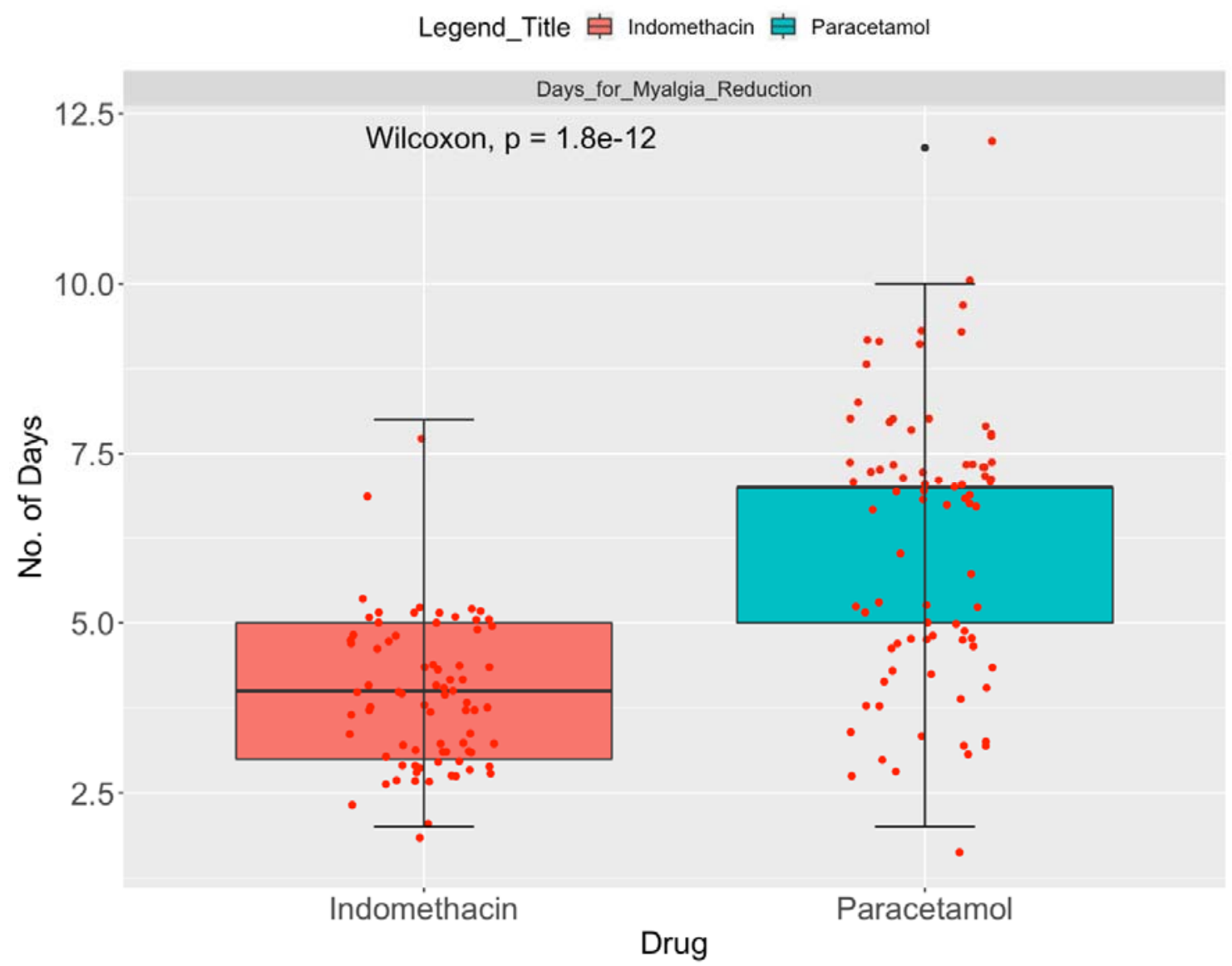

Fig. 3e Number of days of days for myalgia resolution. $\mathrm{N}_{\text {indomethacin }}=77 ; \mathrm{N}_{\text {Paracetamol }}=82$ 
medRxiv preprint doi: https://doi.org/10.1101/2021.07.24.21261007; this version posted October 3, 2021. The copyright holder for this preprint (which was not certified by peer review) is the author/funder, who has granted medRxiv a license to display the preprint in perpetuity. It is made available under a CC-BY-ND 4.0 International license .

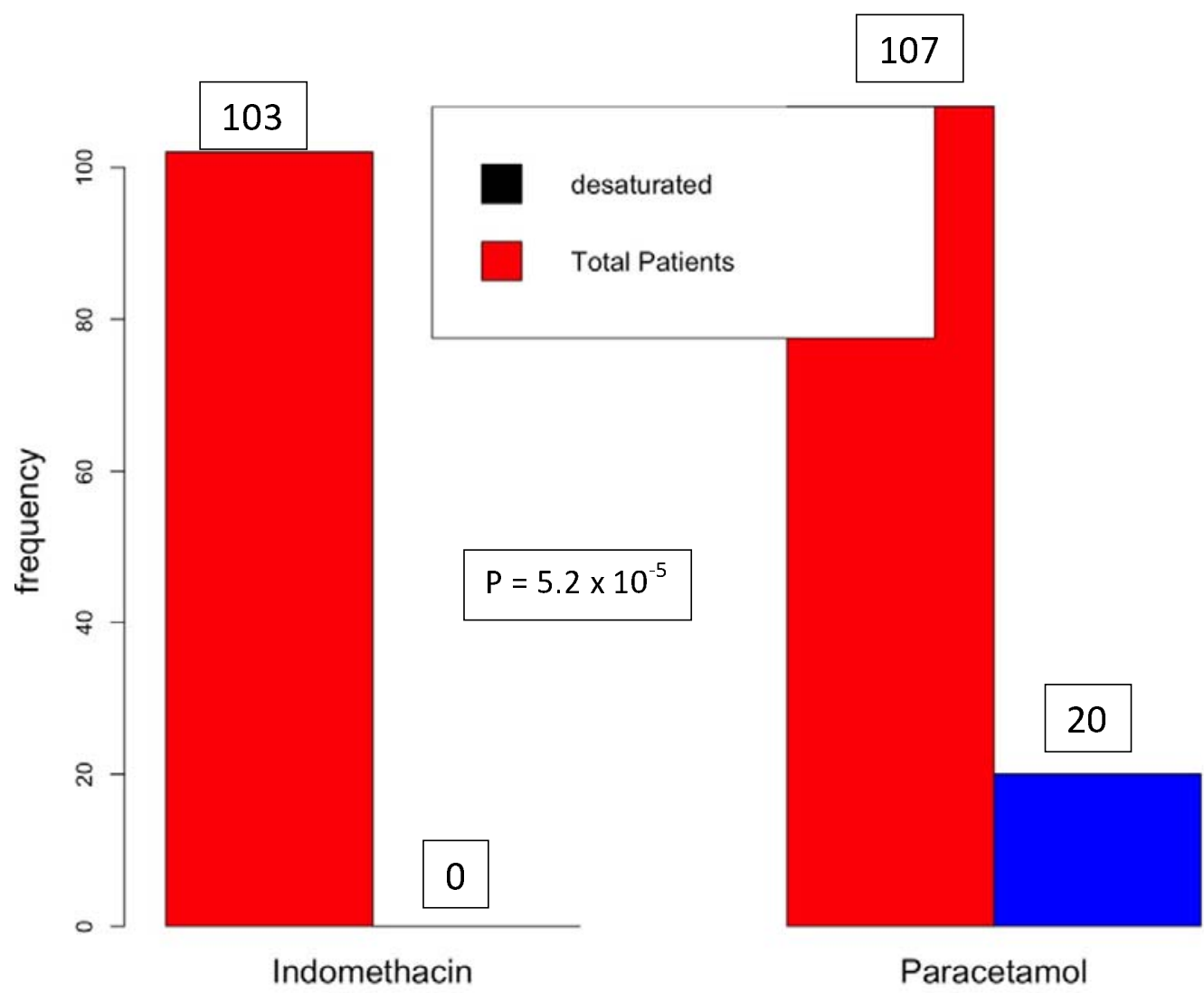

Fig. 4. Number of Patients Desaturated 
medRxiv preprint doi: https://doi.org/10.1101/2021.07.24.21261007; this version posted October 3, 2021. The copyright holder for this preprint (which was not certified by peer review) is the author/funder, who has granted medRxiv a license to display the preprint in perpetuity.

It is made available under a CC-BY-ND 4.0 International license .

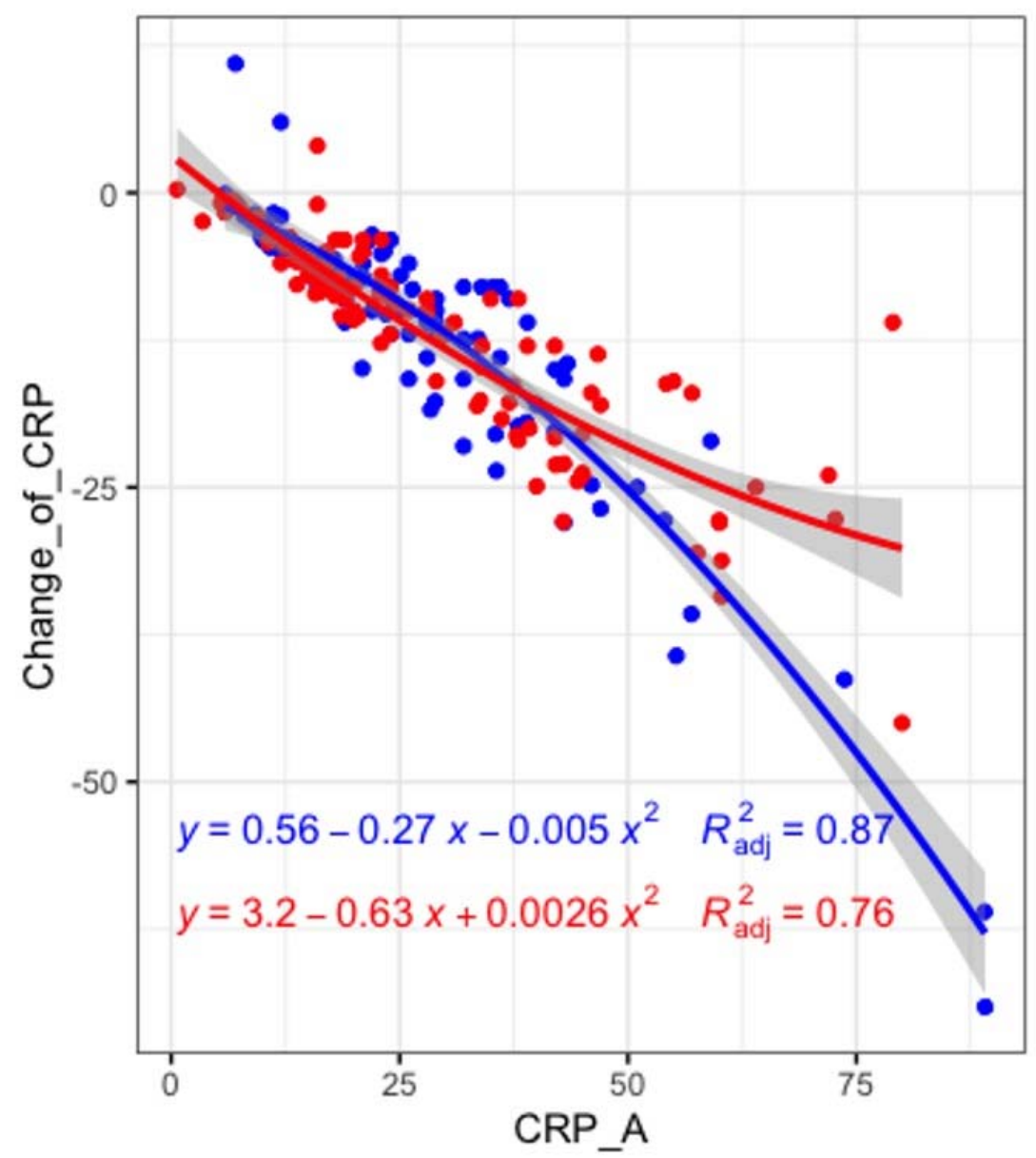

Drug

-c Indomethacin
¿r Paracetamol

Fig. 5 Change in CRP vs. CRP on admission 
medRxiv preprint doi: https://doi.org/10.1101/2021.07.24.21261007; this version posted October 3, 2021. The copyright holder for this preprint (which was not certified by peer review) is the author/funder, who has granted medRxiv a license to display the preprint in perpetuity. It is made available under a CC-BY-ND 4.0 International license.

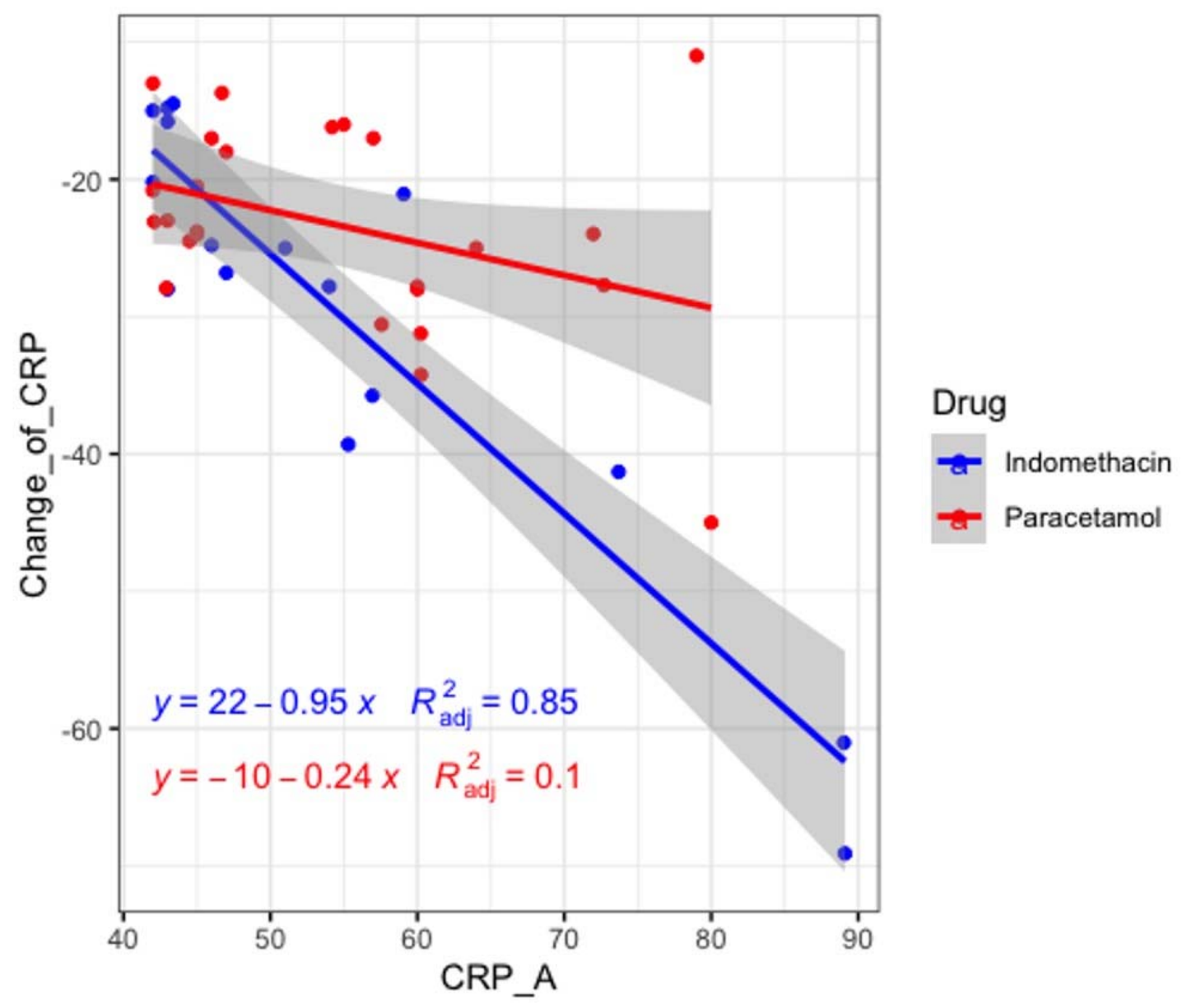

Fig. 6 Change in CRP vs. CRP on admission - A closer look of higher CRP on admission 
medRxiv preprint doi: https://doi.org/10.1101/2021.07.24.21261007; this version posted October 3, 2021. The copyright holder for this preprint (which was not certified by peer review) is the author/funder, who has granted medRxiv a license to display the preprint in perpetuity. It is made available under a CC-BY-ND 4.0 International license .

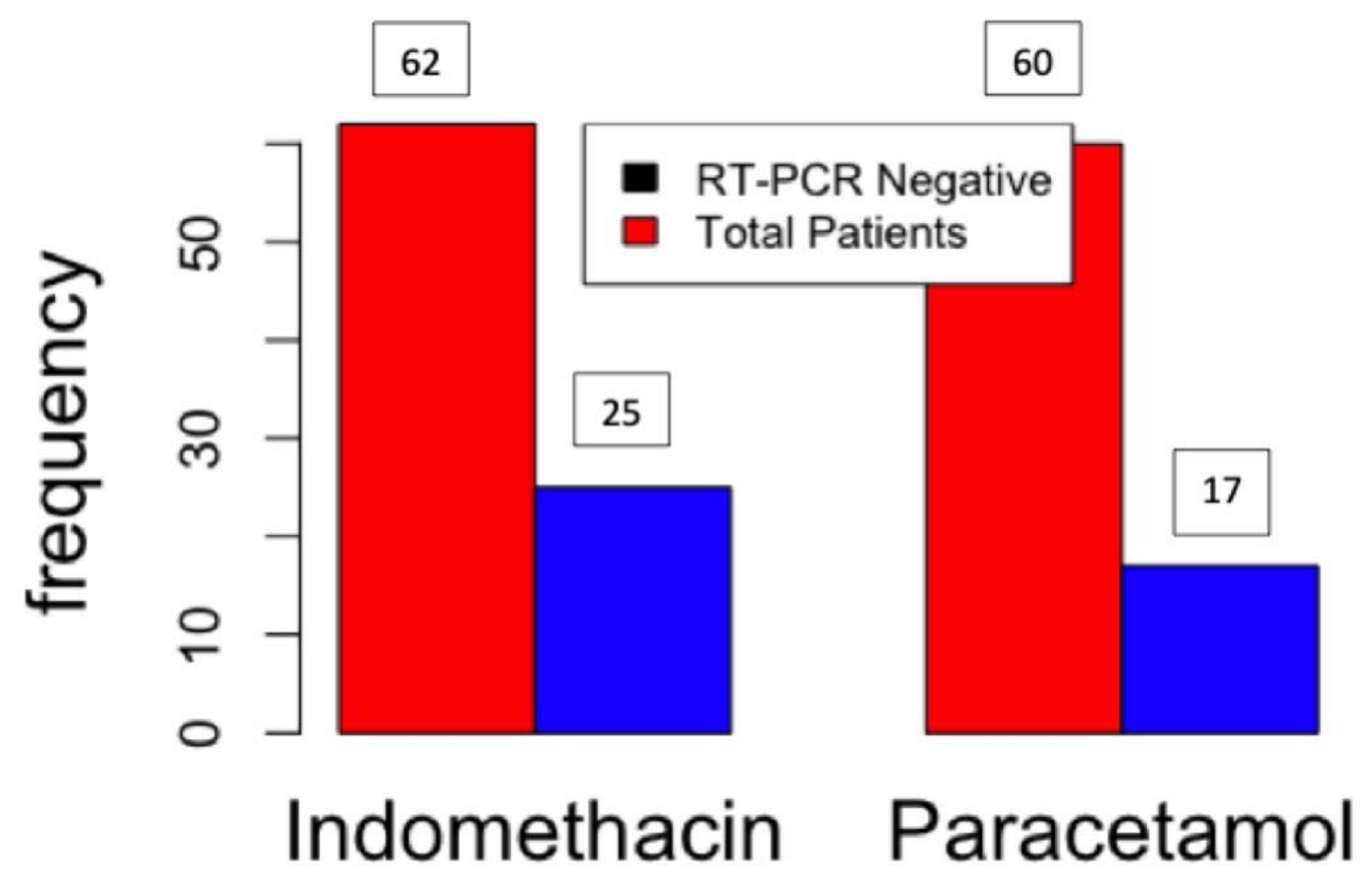

Fig. 7 RT-PCR at the seventh day in both the arms 


\section{Kidney and Liver Function at Admission}

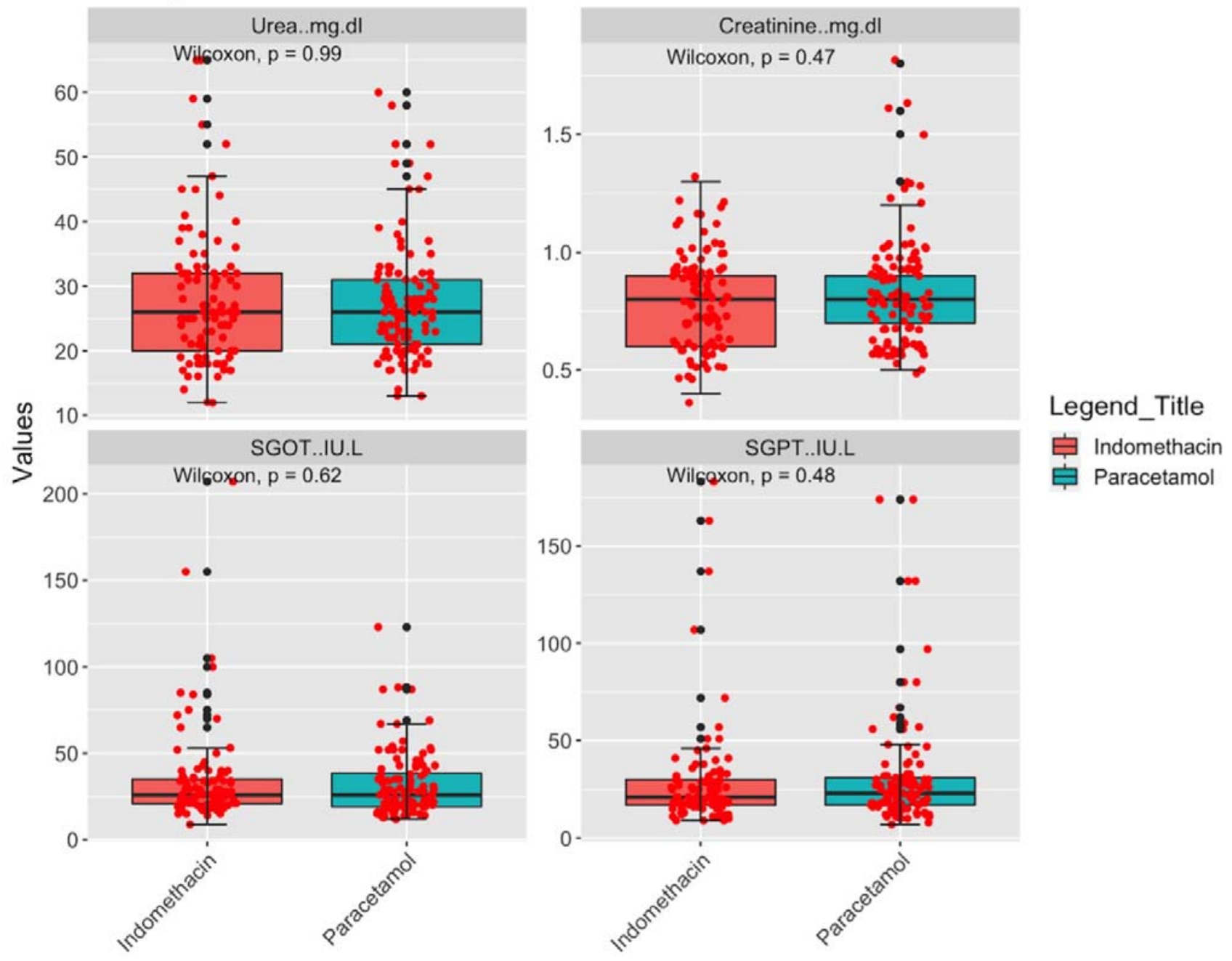

Fig. 8 Kidney and Liver function test on admission 


\section{Kidney and Liver Function at Discharge}

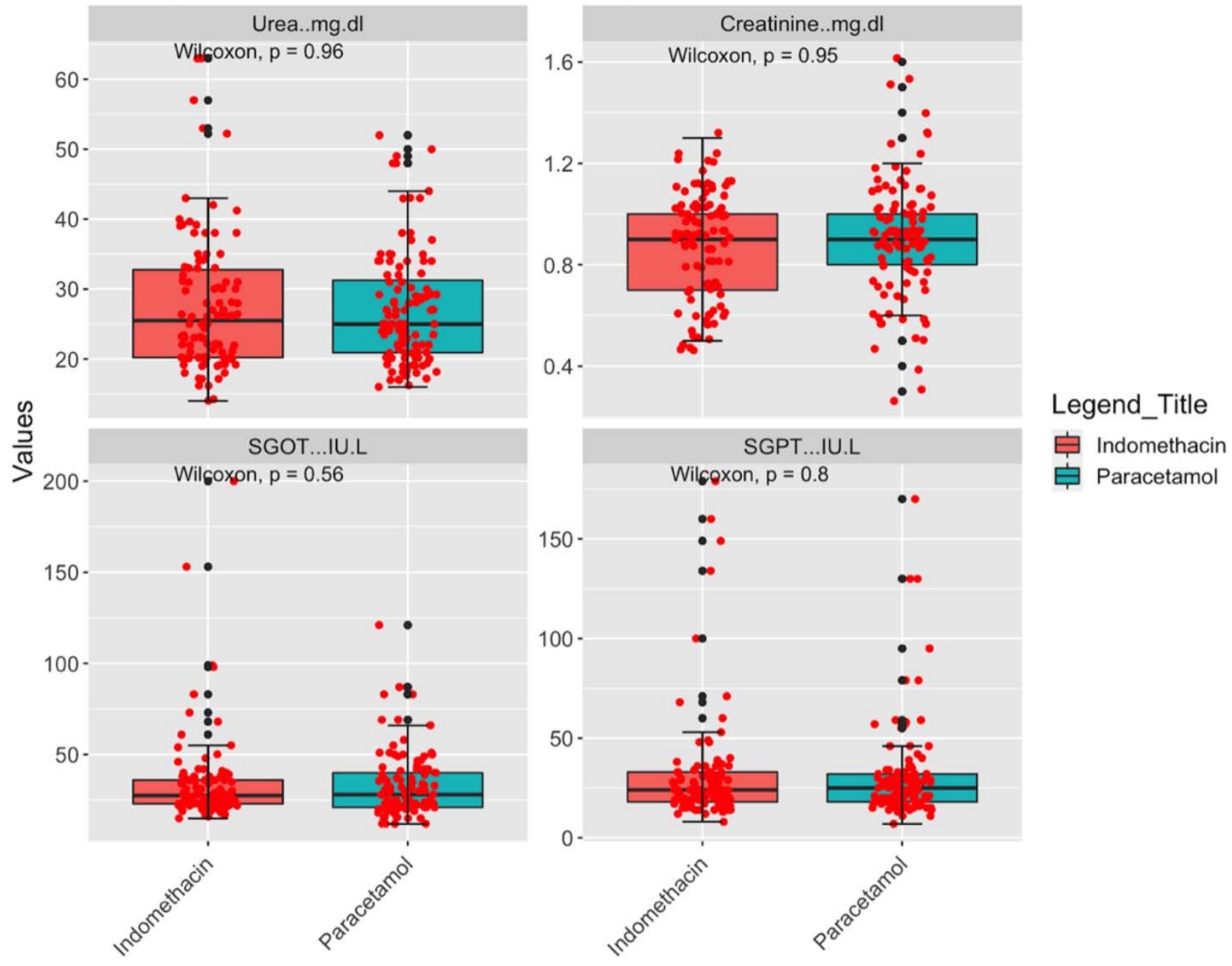

Fig. 9 Kidney and Liver function test on discharge 


\section{Supplementary Appendix}

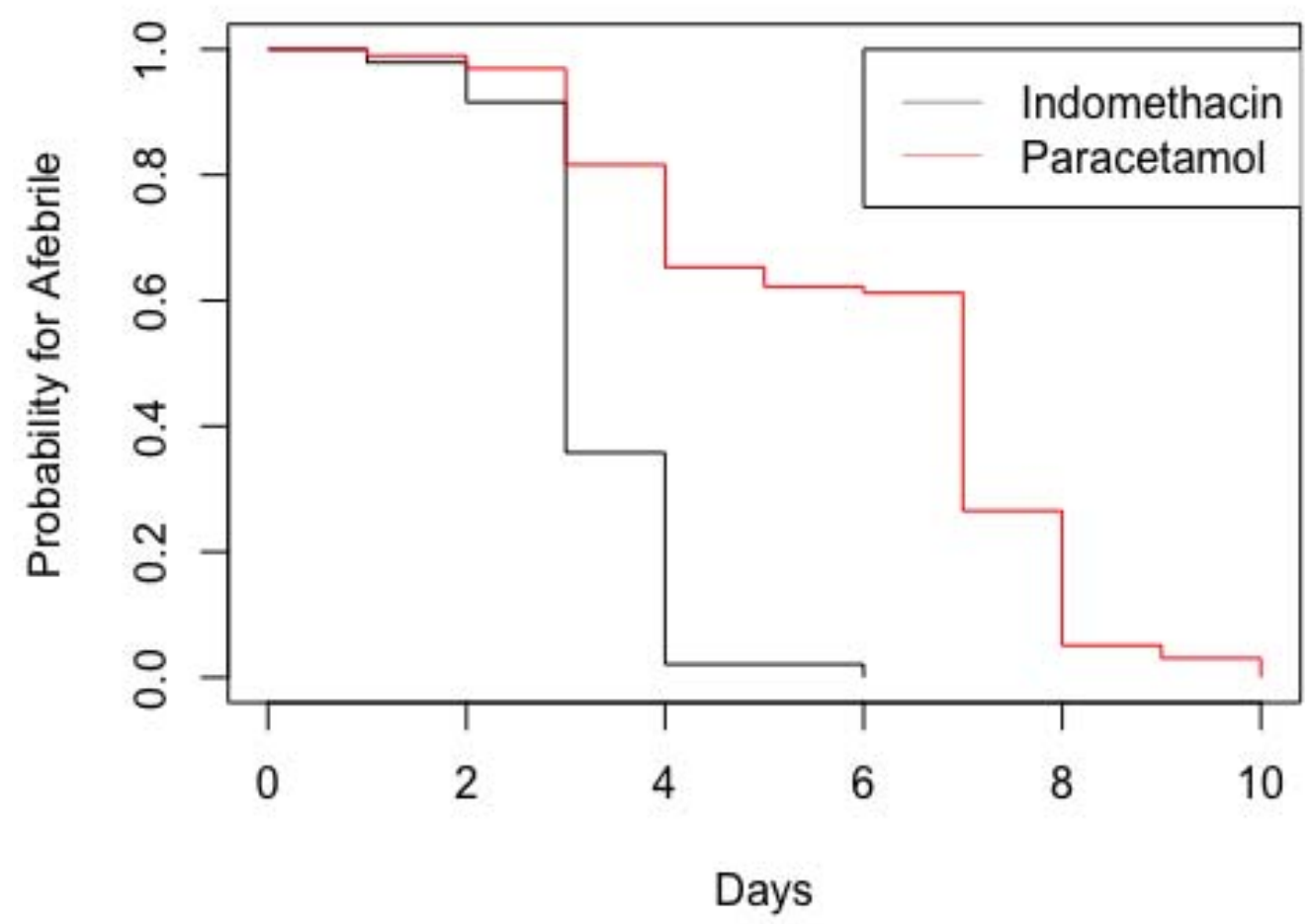

Fig. S1 Kaplan-Meir estimate for fever reduction

\begin{tabular}{|l|r|r|r|r|r|r|}
\hline Covariates & \multicolumn{1}{|c|}{ Reg. Coeff } & exp(coef) & \multicolumn{1}{c|}{$z$} & \multicolumn{1}{c|}{$\operatorname{Pr}(>|z|)$} & \multicolumn{1}{c|}{ Lower 0.95 } & Upper 0.95 \\
\hline Treatment & -2.56955 & 0.07657 & -8.928 & $<2 \mathrm{e}-16$ & 0.04356 & 0.1346 \\
\hline Age & 0.013903 & 1.014 & 1.463 & 0.1436 & 0.99528 & 1.0331 \\
\hline CT Score & -0.090987 & 0.91303 & -1.724 & 0.0848 & 0.82328 & 1.0126 \\
\hline Gender & -0.195889 & 0.822104 & -0.878 & 0.3799 & 0.53093 & 1.273 \\
\hline $\begin{array}{l}\text { CRP on } \\
\text { admission }\end{array}$ & 0.005697 & 1.005713 & 0.876 & 0.3812 & 0.99297 & 1.0186 \\
\hline Comorbidity & -0.229415 & 0.794999 & -1.21 & 0.2262 & 0.54827 & 1.1528 \\
\hline
\end{tabular}

Table S1: Cox Regression results for Fever with either indomethacin or paracetamol treatment; $\mathrm{N}=193 ; \mathrm{N}_{\text {indomethacin }}=95 ; \mathrm{N}_{\text {Paracetamol }}=98$ 


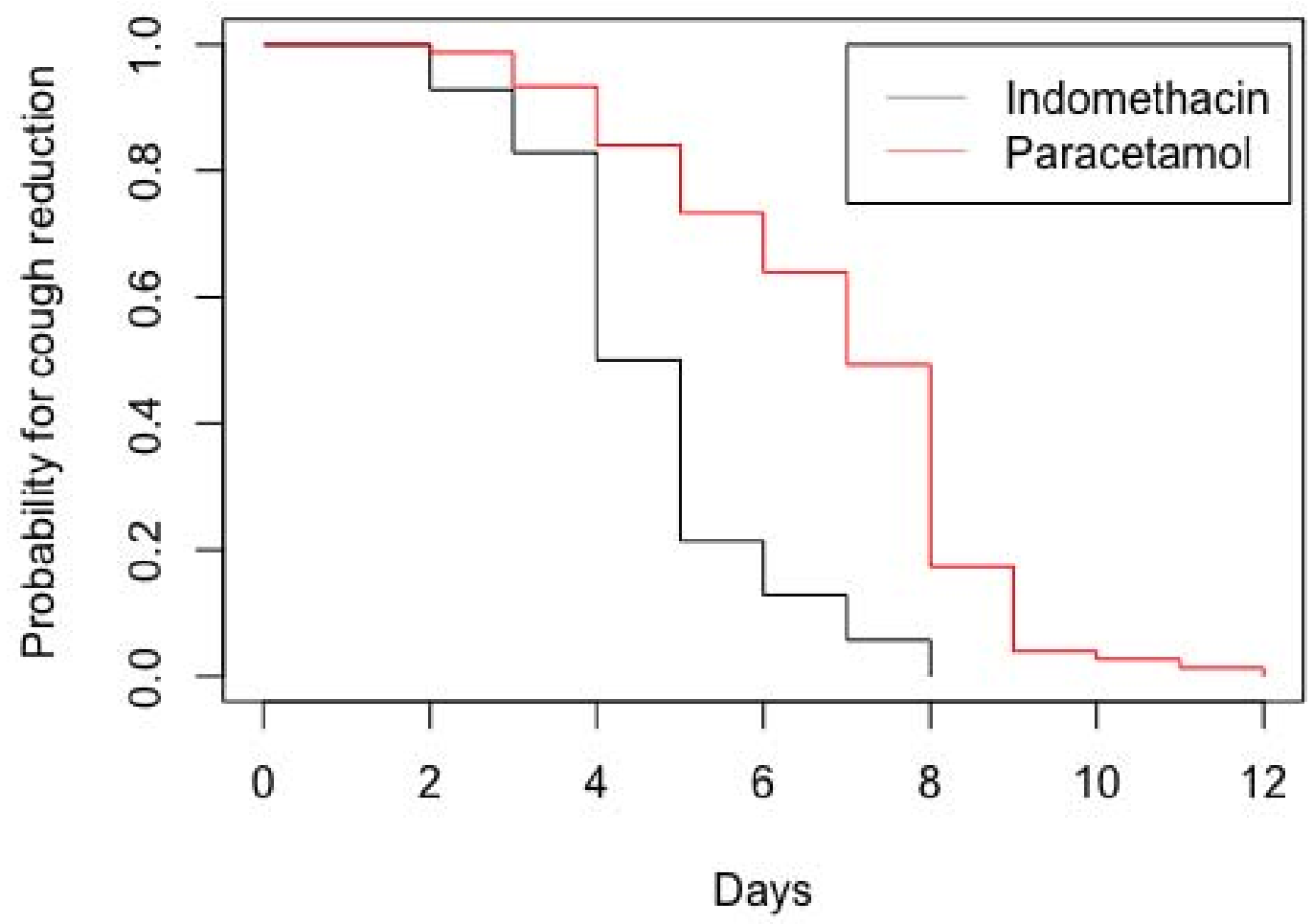

Fig S2. Kaplan-Meir estimate for cough reduction

\begin{tabular}{|l|r|r|r|r|r|r|}
\hline Covariates & \multicolumn{1}{|c|}{ Reg. Coeff } & exp(coef) & \multicolumn{1}{c|}{$\mathrm{z}$} & $\operatorname{Pr}(>|z|)$ & Lower 0.95 & \multicolumn{1}{c|}{ Upper 0.95} \\
\hline Treatment & -2.314587 & 0.098807 & $-7.82 \mathrm{E}+00$ & $5.48 \mathrm{E}-15$ & 0.0553 & 0.1766 \\
\hline age & 0.012633 & 1.012713 & 1.36 & 0.17381 & 0.9944 & 1.0313 \\
\hline CT Score & -0.164531 & 0.848291 & -2.919 & 0.00352 & 0.7596 & 0.9474 \\
\hline Gender & -0.173516 & 0.840704 & -0.726 & 0.46779 & 0.5263 & 1.3429 \\
\hline $\begin{array}{l}\text { CRP on } \\
\text { admission }\end{array}$ & 0.002738 & 1.002742 & 0.392 & 0.69537 & 0.9891 & 1.0166 \\
\hline Comorbidity & -0.030203 & 0.970248 & $-1.66 \mathrm{E}-01$ & 0.86838 & 0.6788 & 1.3868 \\
\hline $\begin{array}{l}\text { Cough on } \\
\text { admission }\end{array}$ & -0.251273 & 0.77781 & -5.104 & $3.32 \mathrm{E}-07$ & 0.7063 & 0.8566 \\
\hline
\end{tabular}

Table S2: Cox Regression results for Cough with either indomethacin or paracetamol treatment; $\mathrm{N}=145 ; \mathrm{N}_{\text {indomethacin }}=70 ; \mathrm{N}_{\text {Paracetamol }}=75$ 


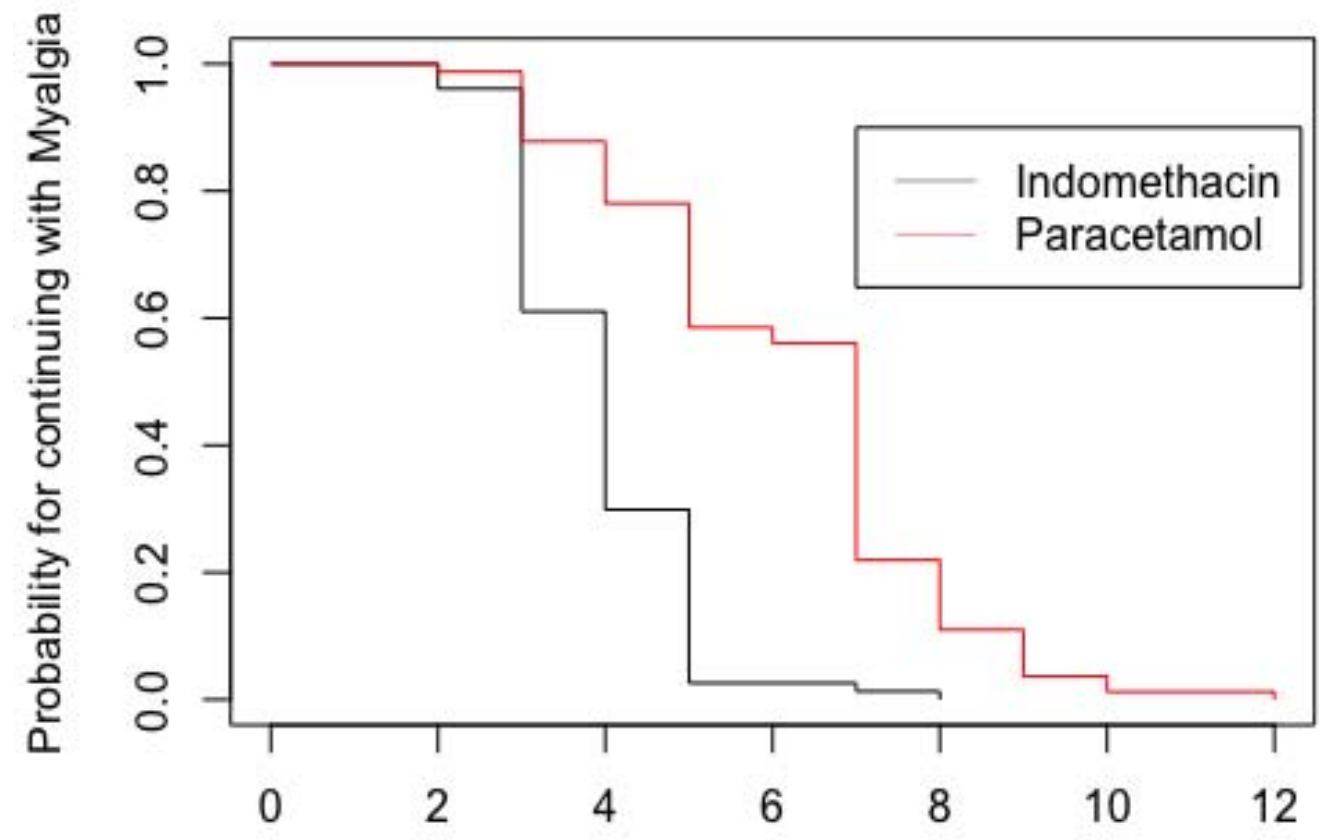

Days

Fig S3. Kaplan - Meir estimate for resolution of Myalgia

\begin{tabular}{|l|r|r|r|r|r|r|}
\hline Covariates & \multicolumn{1}{|c|}{ Reg. Coeff } & \multicolumn{1}{c|}{ exp(coef) } & \multicolumn{1}{c|}{$\mathrm{z}$} & $\operatorname{Pr}(>|\mathrm{z}|)$ & \multicolumn{1}{c|}{ Lower 0.95} & Upper 0.95 \\
\hline Treatment & -2.035077 & 0.13067 & $-7.36 \mathrm{E}+00$ & $1.82 \mathrm{E}-13$ & 0.07601 & 0.2246 \\
\hline Age & 0.004097 & 1.004106 & 0.433 & 0.665 & 0.98565 & 1.0229 \\
\hline CT Score & -0.013054 & 0.987031 & -0.242 & 0.809 & 0.88808 & 1.097 \\
\hline Gender & 0.17193 & 1.187594 & 0.784 & 0.433 & 0.77255 & 1.8256 \\
\hline $\begin{array}{l}\text { CRP on } \\
\text { admission }\end{array}$ & 0.00858 & 1.008617 & 1.258 & 0.208 & 0.99522 & 1.0222 \\
\hline Comorbidity & 0.108482 & 1.114585 & 0.588 & 0.557 & 0.77626 & 1.6004 \\
\hline
\end{tabular}

Table S7 : Cox Regression results for Myalgia with either indomethacin or paracetamol treatment; $\mathrm{N}=159 ; \mathrm{N}_{\text {indomethacin }}=77 ; \mathrm{N}_{\text {Paracetamol }}=82$ 